\title{
Micronutrient Contents of Heritiera fomes Species at Three Saline Zones of the Sundarban Mangrove Forest, Bangladesh
}

\author{
Hasina Mariam1, A. N. M. Alamgir² \\ ${ }^{1}$ Bangladesh Forest Research Institute, Sholoshahar, Chittagong, Bangladesh \\ ${ }^{2}$ Department of Botany, Chittagong University, Chittagong, Bangladesh \\ Email: hasina.mariam@yahoo.com
}

How to cite this paper: Mariam, H. and Alamgir, A.N.M. (2020) Micronutrient Contents of Heritiera fomes Species at Three Saline Zones of the Sundarban Mangrove Forest, Bangladesh. Open Access Library Journal, 7: e6425.

https://doi.org/10.4236/oalib.1106425

Received: May 14, 2020

Accepted: June 26, 2020

Published: June 29, 2020

Copyright $\odot 2020$ by author(s) and Open Access Library Inc.

This work is licensed under the Creative Commons Attribution International License (CC BY 4.0).

http://creativecommons.org/licenses/by/4.0/

(c) (i) Open Access

\begin{abstract}
Micronutrient or essential heavy metals viz. Copper $(\mathrm{Cu})$, Zinc $(\mathrm{Zn})$ and Iron (Fe) distribution trend were studied at the age of 6, 9 and 30 months old $\mathrm{He}$ ritiera fomes seedlings at three distinct saline zones viz. Chandpai (Oligohaline), Jungra (Mesohaline) and Munshiganj (Polyhaline) of the Sundarban mangrove forest. Among the observed micronutrients, Fe content comparatively lower than $\mathrm{Cu}$ and $\mathrm{Zn}$. Relatively higher $\mathrm{Cu}$ was found in the root of 6 month age Heritiera fomes seedlings grown at the Chandpai (Oligohaline) zone but higher content of $\mathrm{Zn}$ was found in the both root and the shoot. At the 9 month age, comparatively higher content of $\mathrm{Cu}$ was found in the root of the seedlings grown at the Jungra (Mesohaline) zone but in the shoot, comparatively higher $\mathrm{Cu}$ content was observed in the seedlings grown at the Munshiganj (Polyhaline) zone. At the age of 30 months, $\mathrm{Cu}$ and $\mathrm{Zn}$ both contents found comparatively lower. At the same age (30 months) Fe content was found relatively higher in the root and the shoot of $H$. fomes seedlings grown at Chandpai saline (Oligohaline) zone but lower in 6-month-old seedlings. At the older age seedlings may appear more metal tolerant/avoider than the younger age seedlings.
\end{abstract}

\section{Subject Areas}

Biotechnology, Ecosystem Science, Edaphology, Environmental Sciences

\section{Keywords}

The Sundarban, Micronutrient, Copper, Zinc, Iron, Oligohaline, Mesohaline, Polyhaline 


\section{Introduction}

The Sundarban is an important tidal mangrove forest from both ecological and economic viewpoints. The forest stands over Ganges basin and playing an outstanding role in balancing the coastal wetland ecosystems in the Bengal basin [1]. The Sundarban covering 10,000 square kilometers of land and water, is part of the world's largest delta (80,000 sq.km) formed from sediments deposited by three great rivers the Ganges, Brahmaputra and Meghna, which covered on the Bengal Basin. About $62 \%$ of the Sundarban lies in the Khulna region of the south western part of Bangladesh, while the remaining 38\% is in India (Lacerda 2001). So, the total area of the Bangladesh Sundarban is $6017 \mathrm{~km}^{2}$, of which $4016 \mathrm{~km}^{2}$ is forest land and the balance is covered by water [2].

Heritiera fomes is a prominent less saline habitat species of the Sundarban mangrove forest. It is more widespread in south Asia and grows exclusively in tidal areas with large stands or grove which reflected their own ecological community. The natural vegetation of the Sundarban mangrove forest depends on natural regeneration. Although mangroves inhabit in different level of saline sediments, their growths generally decline with increasing sediment salinity [3]. Extremely high salinity negatively influences the growth of mangroves seedlings [4]. Based on extensive studies on previous findings in different mangrove seedlings showed the variations on adaptation and respond positively to moderate salinity but negatively influenced by excessive salinity [5]. Now a day as a genus Heritiera is in a threatened category. Due to environmentally induced mortality declines Heritiera fome has been recorded in many parts of the forest [6] [7] [8]. Various abiotic stresses reduce their survival rate through both ionic toxicity and osmotic stress. Since a complex range of interacting abiotic and biotic factors control the availability of nutrients to mangrove species [9].

Micronutrients or some heavy metals like $\mathrm{Fe}, \mathrm{Cu}, \mathrm{Zn}, \mathrm{Mn}, \mathrm{B}, \mathrm{Mo}$ and $\mathrm{Cl}$ are required in small amount and their content in plant components are influenced the metabolic requirements but presence of insufficient and excessive of such micronutrients poses various stresses on plant growth and metabolism [10] [11] [12], and exhibit nutrient stress or toxicity [13]. Fine textured anoxic mangrove sediments are highly efficient and effective sinks for a variety of heavy (trace) metals in which colloidal particles in the sediment scavenged from the water [14]. These underlying sediments, often creating problems of trace metal contamination of sea water and biota. Through mentioned metals $(\mathrm{Cu}, \mathrm{Fe}, \mathrm{Mn}, \mathrm{Ni}$, and $\mathrm{Zn})$ are essential as micronutrient for plants [15] but their excessive presence indicated a high level of metal pollutions in the many mangrove habitats [16]. Since heavy metal concentrations occasionally exceed the EQS (Environment Quality Standard) limit [17]. While exceeded the EQS, deposition of heavy metal like $\mathrm{Pb}$, $\mathrm{Zn}, \mathrm{Cu}$, and $\mathrm{Cd}$ can be absorbed by plants and maybe led to massive tree mortality [18]. However, growth of mangrove seedlings showed more sensitivity to these heavy metals $(\mathrm{Pb}, \mathrm{Cd}, \mathrm{Cu}, \mathrm{Fe}$, etc.). On the other hand, excessive absorption of individual ions may toxic to the early stages of plants or may retard the absorption of other essential plant nutrients. 
The critical stages of the mangrove species are seed germination and survival which completely depends on its physical nature and environmental characteristics [19]. During seed germination and early growth, seedlings depend upon minerals stored in the seed for development, and upon depletion of this source plants become dependent on soil minerals. So, Nutrient availability is one of the major factors influencing mangrove forest structure and productivity. Mangroves usually found to cope with low nutrient availability [20]. Because they usually thrive in saline environment and copped various mechanisms such as selective ion transport that may affect in uptake, distribution, loading and excretion of micronutrients within the plant parts [21] [22].

Along with salinity heavy metals also affect on early growth or regeneration of mangroves [23]-[28]. Older mangrove seedlings appeared to be more metal-tolerant than the younger seedlings due to their more efficient exclusion mechanism. Thus, the effects of metal contamination on young seedlings should be assessed when evaluating the risks posed by heavy metals in an ecosystem [29]. Most of the elements are stored in the soils and dead roots and may serve as a sensitive bio-indicator for metal pollution in these ecosystems [30].

In the Sundarban, the main sources of many heavy metals from industrial discharges as waste particle [31] [32]. On the other hand, the oil and gas mining activities also showed harmful for the mangrove habitats biodiversity and ecosystems. So, such affects may change the hydro edaphic condition of the forest by accelerates to change over the biochemistry of the wetland ecosystem [33] [34].

Therefore, to know the abiotic stresses due to accumulation of micronutrients or essential heavy metals, the present study aims to assess the distribution and toxic content of the such micronutrients or essential heavy metals like $\mathrm{Cu} \mathrm{Zn}$ and Fe in the different parts of the major mangrove viz. Heritiera fomes.

\section{Materials and Methods}

Major mangrove tree species of the Sundarban forest viz. Heritiera fomes Buch, was selected for the present investigation. The Field study was conducted in three different saline zones which are-Chandpai, Jungra and Munshiganj as Oligohaline $\left(4-8 \mathrm{dS}^{-1} \cdot \mathrm{m}\right)$, Mesohaline $\left(8-15 \mathrm{dS}^{-1} \cdot \mathrm{m}\right)$ and Polihaline $\left(>15 \mathrm{dS}^{-1} \cdot \mathrm{m}\right)$ zones respectively were selected as an experiment site. The Chandpai and Jungra zones are in Chandpai range and Munshiganj zone in Satkhira range of the Sundarban forest. Nine sample plots $\left(9 \times 10 \mathrm{~m}^{2}\right)$ have been laid out in these three different saline zones for sample collection. After seed dropping naturally regenerated Heritiera fomes seedlings (6, 9 and 30 months ages) were randomly collected as plant sample from these plots. After washed they excised as root and shoot and then oven dried at $80^{\circ} \mathrm{C}$ until constant weight. The plant samples were ground and processed according to the standard procedure [35] for determining the total copper $(\mathrm{Cu})$, Zinc $(\mathrm{Zn})$ andiron $(\mathrm{Fe})$ by Atomic Absorption Spectrometer (Model: Varian AA240 Atomic Absorption Spectrometer Australia). 


\section{Result and Discussion}

Micronutrient or essential heavy metals like, $\mathrm{Cu}, \mathrm{Zn}$ and $\mathrm{Fe}$ content were analyzed in the Heritiera fomes seedlings. Among them $\mathrm{Cu}$ and $\mathrm{Zn}$ content showed remarkably higher than $\mathrm{Fe}$. Whereas comparatively higher $\mathrm{Cu}$ was found in the root $(2.26 \mathrm{mg} / \mathrm{g})$ but higher $\mathrm{Zn}$ was found in the root and the shoot $(0.788 \mathrm{mg} / \mathrm{g}$ and $0.804 \mathrm{mg} / \mathrm{g}$ ) of 6 months age Heritiera fomes seedlings grown at the Chandpai (oligohaline) zone (Figure 1, Figure 2). However at the 9 months comparatively higher content of $\mathrm{Cu}$ was found in the root of the seedlings $(1.43 \mathrm{mg} / \mathrm{g})$ grown at the Jungra (mesohaline) zone but in the shoot of the 9 months age H. fomes showed comparatively higher $\mathrm{Cu}$ content $(3.18 \mathrm{mg} / \mathrm{g}$ ) at the Munshiganj (polyhaline) zone. These elements are toxic to organisms at high concentration. But they do not inhabit germination but cause strong barrier of seedling growth at relatively low concentration [36]. On the other hand, harmless level of these elements were also found in China mangrove forest [37]. These metals act as micronutrients and need small amount to contribute to plants metabolic necessities.

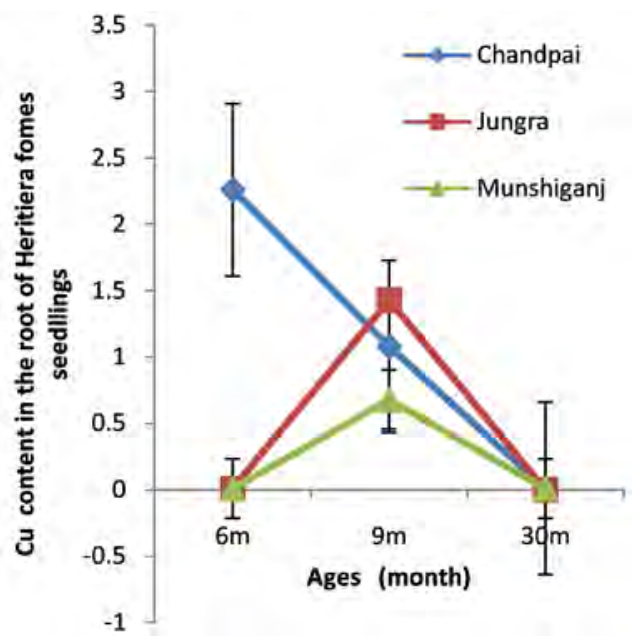

(a)

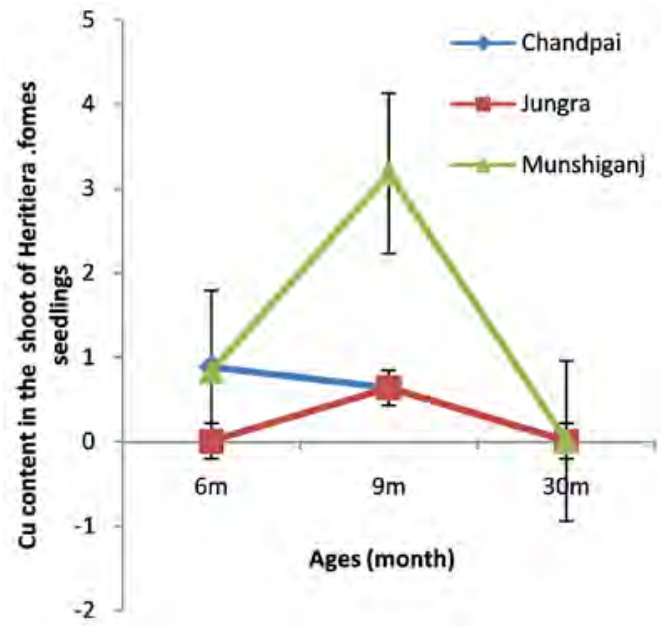

(b)

Figure 1. Cu content in the Root (a) and the Shoot (b) of Heritiera fomes seedlings. 


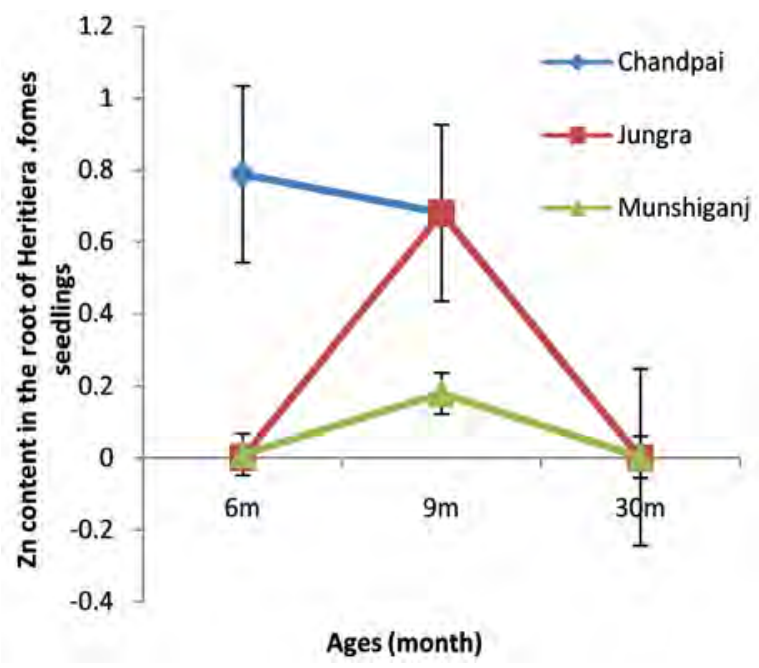

(a)

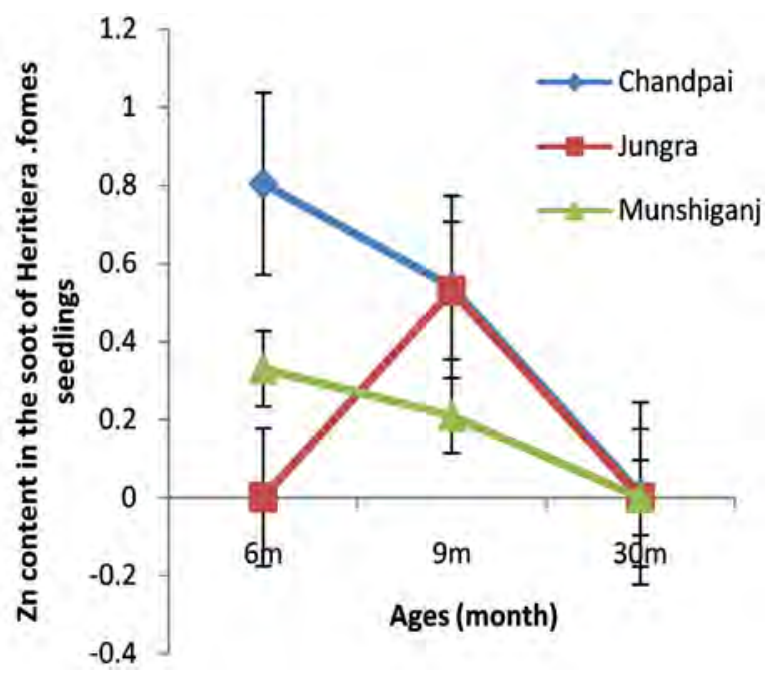

(b)

Figure 2. Zn content in the Root (a) and the Shoot (b) of Heritiera fomes seedlings.

Their lack may damage the whole enzymatic system but excess can alter cell membrane permeability and inhabit enzyme activity by interfere the different metabolic processes. However, $\mathrm{Cu}$ and $\mathrm{Zn}$ were found comparatively lower at the age of 30 months $(0.01 \mathrm{mg} / \mathrm{g}-0.002 \mathrm{mg} / \mathrm{g}$ and $0.01 \mathrm{mg} / \mathrm{g}-0.00004 \mathrm{mg} / \mathrm{g})$ (Figure 1, Figure 2). On the other hand, relatively higher Fe content were found in 30 months root and shoot of $H$. fomes seedlings grown at Chandpai saline (less saline) zone $(0.02 \mathrm{mg} / \mathrm{g}$ ) but lower in 6 months old seedlings (Figure 3$)$. Higher content of $\mathrm{Cu}$ and $\mathrm{Zn}$ were also noticed by many researchers in the early seedling stages [38]. Present observation also noticed that $H$. fomes also showed relatively lower content of micronutrients $(\mathrm{Cu}$ and $\mathrm{Zn})$ in the older age viz. 30 months due to their more efficient ion exclusion or avoiding mechanism. It was also reported that at the older ages' mangrove seedlings appeared to be more metal-tolerant than the younger ages [30]. 


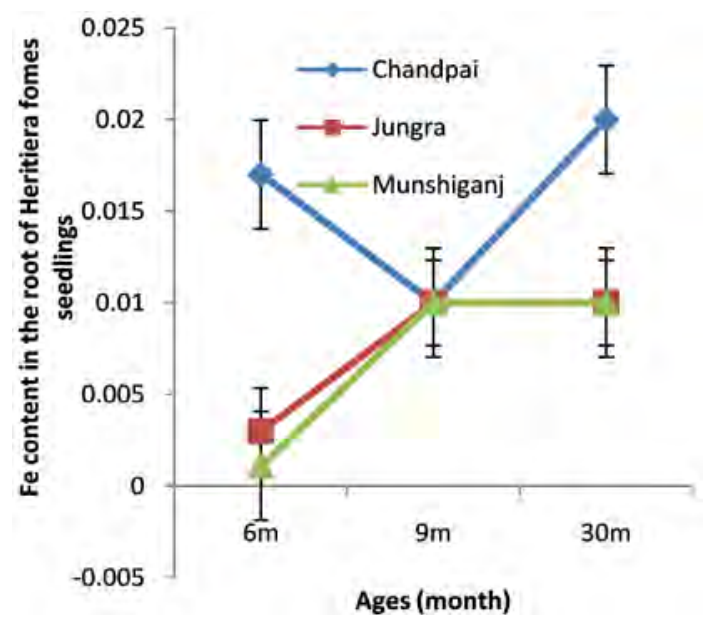

(a)

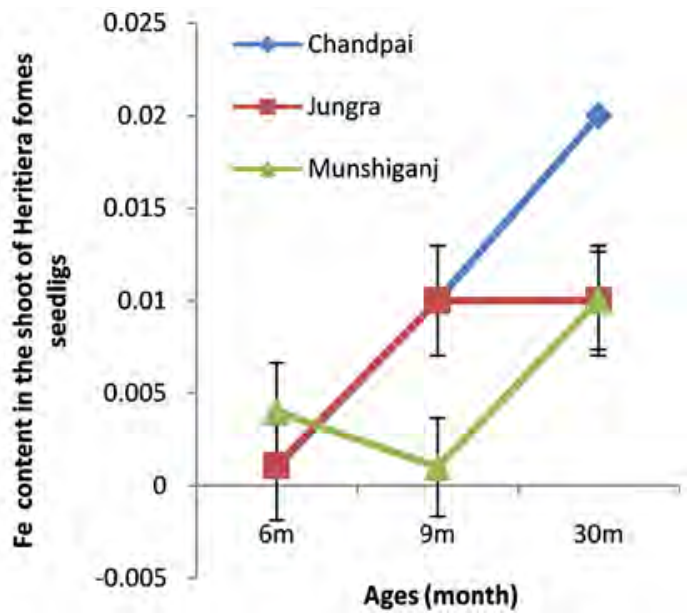

(b)

Figure 3. Fe content in the Root and the shoot of Heritiera fomes seedlings.

\section{Conclusion}

The Heritiera fomes species in early seedling stage are affected with high content of micronutrient or heavy metal and response differently by tolerance of metals in different plant parts and ages. At the older age seedlings appeared to be more metal-tolerant than the younger age seedlings. Thus, the effects of metal contamination on young seedlings should be assessed when evaluating the risks posed by heavy metals in an ecosystem.

\section{Conflicts of Interest}

The authors declare no conflicts of interest regarding the publication of this paper.

\section{References}

[1] Islam, A.K.M.N. (2003) Mangrove Forest Ecology of Sundarbans: The Study of Change in Water, Soil and Plant Diversity. In: Ghosh, A.K. and Mukhopadhya, 
M.K., Eds., Sustainable Environment: A Statistical Analysis, Oxford University Press, New Delhi, 126-147.

[2] Lacerda, L.D.D. (2001) Mangrove Ecosystems, Function and Management. Springer, Berlin. https://doi.org/10.1007/978-3-662-04713-2

[3] Katebi, M.N.A. (2001) Sundarbans and Forestry. In: Haidar, Ed., Cyclone 91-An Environmental and Perceptional Study, BCAS, Dhaka, 79-100.

[4] Clough, B.F. and Rews, T.J. (1982) Physiological Processes in Mangroves. In: Clough, B.F., Ed., Mangrove Ecosystems in Australia: Structure, Function and Management, Australian Institute of Marine Science in Association with Australian Natural University Press, Canberra, 195-300.

[5] Smith, S.M. and Snedaker, S.C. (1995) Salinity Responses in Two Populations of Viviparous Rhizophora mangle L. Seedlings. Biotropica, 27, 435-440. https://doi.org/10.2307/2388955

[6] Wang, B.R., Devenport, J., Volkov, V. and Amtmann, A. (2006) Low Directional Sodium Influx into Root Cells Restricts Net Sodium Accumulation Thellungiella halophilla, a Salt Tolerant Relative of Arobidopsis thaliana. Journal of Experimental Botany, 57, 161-170. https://doi.org/10.1093/jxb/erj116

[7] Polidoro, B.A., Carpenter, K.E., Collins, L., Duke, N.C., Ellison, A.M., et al. (2010) The Loss of Species: Mangrove Extinction Risk and Geographic Areas of Global Concern. PLoS ONE, 5, e10095. https://doi.org/10.1371/journal.pone.0010095

[8] Siddiqi (1996) A Review of Regeneration Problem of Mangroves with Particular Reference to Bangladesh to Bangladesh. Mangrove Newsletter (Japan), No. 16, 2-8.

[9] Siddiq (2001) Mangrove Forestry in Bangladesh. Institute of Forestry \& Environmental Sciences University of Chittagong, Chittagong, 201 p.

[10] Reef, R., Feller, C.I. and Lovelock, C.E. (2010) Nutrition of Mangroves. Oxford University Press, Oxford. https://doi.org/10.1093/treephys/tpq048

[11] Jones, J.B., Wolf, B. and Mills, H.A. (1991) Plant Analysis Handbook: A Practical Sampling Preparation, Analysis and Interpretation Guide. Micro-Macro Publishing, Athens.

[12] Vangronsveld, J. and Clijsters, H. (1994) Toxic Effects of Metals. In: Fargo, M.E., Ed., Plants and the Chemical Elements: Biochemistry, Uptake, Tolerance and Toxicity, VCH Press, Weinheim, 149-177. https://doi.org/10.1002/9783527615919.ch6

[13] Chiu, C.Y., Hsiu, F.S., Chen, S.S. and Chou, C.H. (1995) Reduced Toxicity of Cu and $\mathrm{Zn}$ to Mangrove Seedlings in Saline Environments. Botanical Bulletin of Academia Sinica, 36, 19-24.

[14] Umar, S., Moinuddin and Iqbal, M. (2005) Heavy Metals: Availability, Accumulation and Toxicity in Plants. In: Dwivedi, P. and Dwivedi, R.S., Eds., Physiology of Abiotic Stress in Plants, Dr. Updesh Purohit for Agrobios, Jodhpur, 325-343.

[15] Saenger, P. and McConchie, D. (2004) Heavy Metal in Mangroves Methodology, Monitoring and Management. ENVIS Forestry Bulletin, 4, 52-62.

[16] Kar, D.P., Sur, S.K., Mandal, T., Saha and Kole, R.K. (2007) Assessment of Heavy Metal Pollution in Surface Water. International Journal of Environmental Science and Technology, 5, 119-124. https://doi.org/10.1007/BF03326004

[17] Mac Farlane, G.R. and Burchett, M.D. (2002) Toxicity, Growth and Accumulation Relationships of Copper, Lead and ZNIC in the Grey Mangrove Avicennia marina (Forsk.) Vierh. Marine Environmental Research, 54, 65-84. https://doi.org/10.1016/S0141-1136(02)00095-8

[18] Wahid, S.M., Mukand, S.B. and Bhuiyan, A.R. (2007) Hydrologic Monitoring and 
Analysis in the Sundarbans Mangrove Ecosystem, Bangladesh. Journal of Hydrolo$g y, 332,381-395$. https://doi.org/10.1016/j.jhydrol.2006.07.016

[19] Davari, A., Danchkar, A., Khorasani, N. and Poorbagher, H. (2010) Heavy Metal Contamination of Sediments in Mangrove Forests of the Persian Gulf. Journal of Food Agriculture \& Environment, 8, 1289-1284.

[20] Khan, M.A. and Gul, B. (2006) Halophytes Seed Germination. In: Ecophysiology of High Salinity Tolerant Plants, Springer, Dordrecht, 11-30. https://doi.org/10.1007/1-4020-4018-0_2

[21] Boto, K.G. and Welhington, J.T. (1983) Phosphorus and Nitrogen Nutritional Status of a Northern Australian Mangrove Forest. Marine Ecology Progress Series, 11, 63-69. https://doi.org/10.3354/meps011063

[22] Boto, K.G. (1992) Nutrients and Mangroves. In: Connell, D.W. and Hawker, D.W., Eds., Pollution in Tropical Aquatic Systems, CRC Press, Boca Raton, 129-146. https://doi.org/10.1201/9781351075879-5

[23] Li, M.S. (1997) Nutrient Dynamic of a Futian Mangrove Forest in Shenzhen, South China. Estuarine, Coastal and Shelf Science, 45, 463-472. https://doi.org/10.1006/ecss.1996.0201

[24] Hutchings, P. and Saenger, P. (1987) The Ecology of Mangroves. University of Queensland Press, St Lucia.

[25] Clark, M.W., McConche, D., Lewis, D.W. and Seanger, P. (1998) Redox Stratification and Heavy Metal Partitioning in Avicennia Dominated Mangrove Sediments; a Geochemical Model. Chemical Geology, 149, 147-171. https://doi.org/10.1016/S0009-2541(98)00034-5

[26] Preda, M. and Cox, M.E. (2002) Trace Metal Occurrence and Distribution in Sediments and Mangroves, Pumicestone Region, Southeast Queensland, Australia. Environment International, 28, 433-449. https://doi.org/10.1016/S0160-4120(02)00074-0

[27] Marchard, C.E., Lallier-verges, F., Baltzer, P., Alberic, D., Cossa and Baillif, P. (2006) Heavy Metals Distribution in Mangrove Sediments along the Mobile Coastline of French Guiana. Marine Chemistry, 98, 1-17. https://doi.org/10.1016/j.marchem.2005.06.001

[28] Anderson, L.E., Melville, F. and Jolley, D. (2008) An Assessment of an Oil Spill in Gladstone, Australia. Impacts on Intertidal Areas at One Month Post-Spill. Marine Pollution Bulletin, 57, 607-615. https://doi.org/10.1016/j.marpolbul.2008.04.023

[29] Yu, R.L., Xing, Y., Zhao, Y.H., Hu, G.R. and Tu, X.L. (2008) Heavy Metal Pollution in Intertidal Sediments from Quanzhou Bay, China. Journal of Environmental Sciences, 20, 664-669. https://doi.org/10.1016/S1001-0742(08)62110-5

[30] Wang, Y., Qiu, Q., Xin, G., Yang, Z., Zheng, J. and Ye, Z. (2012) Heavy Metal Contamination in Vulnerable Mangrove Swamp in South China. Environmental Monitoring and Assessment, 185, 5775-5787. https://doi.org/10.1007/s10661-012-2983-4

[31] Alongi, D.M., Clough, P., Dision and Tirendi, F. (2003) Nutrient Partitioning and Storage in Arid-Zone Forests of the Mangroves Rhizophora stylosa and Avicennia marina. Trees, 17, 51-60. https://doi.org/10.1007/s00468-002-0206-2

[32] Rahaman, M.M., Lu, H.L., et al. (2009) A Brief Review on Pollution and Ecotoxicologic Effects on Sundarbans Mangrove Ecosystem in Bangladesh. International Journal of Environmental Engineering, 1, 369-383. https://doi.org/10.1504/IJEE.2009.027982

[33] Iftekhar, M.S. and Saenger, M.R. (2008) Vegetation Dynamics in the Bangladesh 
Sundarbans Mangroves: A Review of Forest Inventories. Wetlands Ecology and Management, 16, 291-312. https://doi.org/10.1007/s11273-007-9063-5

[34] Allen, S.E. (1974) Chemical Analysis of Ecological Materials. Blackwell Scientific Publication, Oxford.

[35] Li, W., Khan, M.A., Yamaguchi and Kamiya, Y. (2005) Effects of Heavy Metals on Seed Germination and Early Seedling Growth of Arabidopsis thaliana. Plant Growth Regulation, 46, 45-50. https://doi.org/10.1007/s10725-005-6324-2

[36] Lian, Y., Xu, J., Lin, P., Meguro, S., Kawachi, S. and McGuinness, K.A. (1997) Dispersal, Establishment and Survival of Ceriops tagal Propagules in a North Australian Mangrove Forest. Oecologia, 109, 80-87. https://doi.org/10.1007/s004420050061

[37] Thomas and Fernandez (2006) Incidence of Heavy Metals in the Mangrove Flora and Sediments in Kerala, India. Journal Hydrobiology, 352, 77-87. https://doi.org/10.1007/978-94-011-5234-1_9

[38] Mahmood, H. and Saberi, O. (2007) Micronutrient Contents of Field Grown Seedlings, and Trees of a Mangrove Species, Bruguiera parviflora (Wight \& Arnold) in the Kuala Selangor Nature Park, Malaysia. Indian Forester, 133, 1057-1062. 